\title{
RANCANG BANGUN SISTEM INFORMASI COLLECTING DAN PLOTTING PERTANAHAN (SI-COPILOT) UNTUK KEGIATAN INVENTARISASI TANAH INSTANSI PEMERINTAH DI KANTOR PERTANAHAN KABUPATEN KLATEN
}

\author{
Taufik Nur Rokhman', Bambang Suyudi'2, Nuraini Aisiyah ${ }^{3}$ \\ ${ }^{1}$ Kantor Wilayah ATR/BPN Provinsi Sulawesi Utara, Jl. 17 Agustus, Kota Manado \\ ${ }^{2}$ Kantor Wilayah ATR/BPN Provinsi Kalimantan Selatan, Jl. D.I. Panjaitan No. 20, Antasan \\ Besar, Kec. Banjarmasin Tengah, Kota Banjarmasin \\ ${ }^{3}$ Sekolah Tinggi Pertanahan Nasional, Jl. Tata Bhumi No. 5, Banyuraden, Yogyakarta \\ Email: taufiknurrokhman@gmail.com
}

Naskah diterima: 22 Agustus 2021; revisi: 20 September 2021; disetujui: 20 September 2021

\begin{abstract}
:
Various obstacles in collecting textual data and spatial data in INTIP activities at Regional Land Office of Klaten Regency make it difficult in achieving the expected targets and implementing inefficient data collection. The impact that emerged later was the difficulty in integration between textual data and spatial data. Time efficiency of the implementation of activities needs a mechanism and a system for collecting and managing data from INTIP. The objectives of this research are; designing information systems to answer existing problems and constraints and explaining the benefits of information systems for users involved in INTIP activities. The method used is Research and Development (R\&D). Data collection techniques were carried out through: interviews, observations and document analysis. Data analysis was done descriptively. The results of the study indicate that: (1) The design of the information system consists of several stages, namely: (a) analysis of users and system requirements, (b) database creation, (c) information system design, (d) trial and evaluation of information systems, (e) improvement of information systems; (2) The benefit of the Land Collecting and Plotting Information System (Si-Copilot) in INTIP activities is that it is able to collect, process, and manage textual data and spatial data simultaneously when collecting data at the location of INTIP. This can be easier for users to integrate textual and spatial data so that it can help accelerating the completion of INTIP work.
\end{abstract}

Keywords: information systems, textual data, spatial data, INTIP.

\begin{abstract}
Abstrak:
Berbagai kendala dalam pengumpulan data tekstual dan data spasial dalam kegiatan INTIP di Kantor Pertanahan Kabupaten Klaten, mengakibatkan sulitnya untuk mencapai target yang dipenuhi dan pelaksanaan pengumpulan data yang tidak efisien. Dampak yang muncul kemudian adalah sulitnya integrasi antara data tekstual dan data spasial. Untuk efisiensi waktu terhadap pelaksanaan kegiatan perlu dibangun sebuah mekanisme dan sistem pengumpulan serta manajemen data dari INTIP tersebut. Tujuan penelitian ini adalah; merancang bangun sistem informasi untuk menjawab dari permasalahan dan kendala yang ada dan menjelaskan manfaat dari sistem informasi untuk pengguna yang terlibat dalam kegiatan INTIP. Metode yang digunakan adalah Penelitian dan Pengembangan (Research and Development atau R\&D). Teknik pengumpulan data dilakukan melalui: wawancara, observasi dan studi dokumen. Analisis data dilakukan secara deskriptif. Hasil penelitian menunjukkan bahwa: (1) Perancangan sistem informasi terdiri dari beberapa tahapan yaitu: (a) analisis kebutuhan pengguna dan sistem, (b) pembuatan basis data, (c) perancangan sistem informasi, (d) uji coba dan evaluasi sistem informasi, (e) perbaikan sistem informasi; (2) Manfaat Sistem Informasi Collecting dan Plotting Pertanahan (Si-Copilot) dalam kegiatan INTIP adalah mampu
\end{abstract}


mengumpul, mengolah, dan manajemen data tekstual dan data spasial secara bersamaan pada saat mengambil data di lokasi INTIP. Hal ini dapat memudahkan pengguna dalam mengintegrasikan data tekstual dan spasial sehingga dapat membantu percepatan penyelesaian pekerjaan INTIP.

Kata Kunci: sistem informasi, data tekstual, data spasial, INTIP.

\section{A. Pendahuluan}

Kemajuan dan perkembangan teknologi sekarang ini merupakan sesuatu yang tidak dapat dihindari, hal ini berjalan seiring dengan perkembangan pengetahuan dan tuntutan kebutuhan (Hayati, 2019). Inovasi perkembangan informasi dan teknologi di era revolusi industri 4.0 telah sampai pada rekayasa komputer dan genetika, nano teknologi dan inovasi lain yang berkaitan dengan komunikasi dan internet (Satya, 2018). Arah perkembangan ini juga sebagai jawaban tantangan dari Revolusi Industri 4.0 yang dimulai dari tahun 2000an. Hardiansyah (2020) juga menjelaskan bahwa Revolusi Industri 4.0 menggunakan automatisasi data sehingga mempercepat pertukaran informasi, meningkatkan pelayanan publik dan mengurangi biaya. Pemerintah dalam pelayanan publik dituntut untuk dapat meningkatkan kualitas pelayanannya terhadap masyarakat, tuntutan ini memaksa sejumlah kantor layanan publik dengan mulai meninggalkan model dan konsep pemerintahan tradisional yang identik dengan menggunakan kertas pada birokrasi dan administrasinya (Surdin, 2016).

Tantangan revolusi industri 4.0 juga mendorong perubahan tata kelola pemerintahan ke arah E-government. E-government merupakan suatu transformasi kegiatan pemerintah yang berguna meningkatkan efisiensi dan efektivitas layanan publik dengan menggunakan inovasi teknologi digital (Forman, 2005). Inovasi ini disambut positif oleh karyawan pemerintah sebagai upaya mempermudah birokrasi dan manajemen administrasi yang cepat dan tepat. E-goverment juga dapat meningkatkan kualitas hubungan antara pemerintah dan masyarakat serta stakeholder lainnya yang saling berkepentingan (Indrajit, 2002). Pada administrasi pertanahan, Abinowo (2019) menjelaskan bahwa e-goverment dan produk turunannya dapat membuka akses informasi yang lebih transaparan dan berpotensi menjadi salah satu alat penyelesaian sengketa dan permasalahan proses pertanahan, baik dalam pengumpulan secara spasial maupun tekstual.

Berdasarkan Peraturan Menteri Agraria dan Tata Ruang/Kepala Badan Pertanahan Nasional Republik Indonesia Nomor 16 Tahun 2020 tentang Organisasi dan Tata Kerja Kementerian Agraria dan Tata Ruang/Badan Pertanahan Nasional menjelaskan bahwa 
Kementerian Agraria dan Tata Ruang/Badan Pertanahan Nasional (Kementerian ATR/BPN) memiliki tugas untuk melaksanakan pemerintahan di bidang pertanahan secara nasional, regional dan sektoral. Kementerian ATR/BPN dalam tugas dan fungsinya memiliki peranan untuk mengelola, transparansi, dan mengembangkan informasi di bidang pertanahan. Untuk mewujudkan hal tersebut, Kementerian ATR/BPN memiliki salah satu kewajiban untuk mengumpulkan, mengolah serta mengelola data pertanahan dimana data pertanahan tersebut berkaitan dengan penguasaan, peruntukkan, penggunaan, dan pemanfaatan tanah instansi pemerintah kemudian menyajikan dalam bentuk sistem informasi pertanahan.

Pemetaan yang baik untuk mendeteksi status dari tanah pemerintah itu sendiri, belum diketahui caranya oleh banyak instansi pemerintah (Kementerian ATR/BPN, 2020). Kementerian ATR/BPN melalui kantor pertanahan kabupaten/kota dan pemerintah daerah setempat melakukan program Inventarisasi Tanah Instansi pemerintah yang selanjutnya disingkat INTIP untuk meningkatkan efisiensi dan mempercepat inventarisasi tanah instansi pemerintah (Kementerian ATR/BPN, 2020). INTIP adalah kegiatan pemerintah untuk melakukan pendataan, pencatatan, dan pelaporan tanah instansi pemerintah sebagai basis data (Petunjuk Teknis Kegiatan INTIP, 2019). Instansi pemerintah yang dimaksud di antaranya; Pemerintah Pusat, Pemerintah Provinsi, Pemerintah Kabupaten/Kota, Pemerintah Desa, BUMN, BUMD, BHMN, Badan Perwakilan Negara Asing, dan Perwakilan Organisasi Internaisonal yang menggunakan dan memanfaatkan tanah di wilayah Republik Indonesia (Petunjuk Teknis Kegiatan INTIP, 2019).

Pemanfaatan tanah pemerintah menjadi salah satu isu penting dalam rangka mendukung tujuan Negara untuk mewujudkan sebesar-besar kemakmuran rakyat. Program INTIP dilaksanakan dalam rangka mewujudkan ketersediaan basis data tanah instansi pemerintah yang akurat dan mutakhir. Database tersebut sangat penting karena untuk memantau dan mengevaluasi setiap perbuatan hukum yang boleh atau tidak boleh dilakukan atas tanah instansi pemerintah. Data tanah instansi pemerintah baik yang sudah bersertipikat maupun belum bersertipikat (tekstual maupun spasial) belum dimiliki secara lengkap oleh Kementerian ATR/BPN. Hal ini membutuhkan perhatian bersama sehingga perlu diselenggarakan kegiatan INTIP yang dilaksanakan oleh Bidang dan/atau Seksi yang menangani tugas-tugas di bidang pemanfaatan tanah pemerintah (Petunjuk Teknis Kegiatan INTIP, 2019).

Kantor Pertanahan Kabupaten Klaten, pada tahun 2020 memiliki target untuk menyelesaikan kegiatan INTIP yang tersebar di 123 desa dari 8 kecamatan di Kabupaten Klaten (Kantor Pertanahan Kabupaten Klaten, 2020). Banyaknya target yang harus diselesaikan, pelaksanaan kegiatan INTIP di Kantor Pertanahan Kabupaten Klaten tidak 
hanya melibatkan seksi 3 yakni Seksi Pengadaan Tanah dan Pengembangan yang merupakan penanggung jawab kegiatan, tetapi juga melibatkan beberapa staf dari seksi yang lainnya.

Kegiatan ini pada kenyataannya sudah dimulai dari bulan Januari hingga bulan Agustus, dan baru sebanyak 18 desa yang terselesaikan dari target keseluruhan 123 desa. Dapat dikatakan bahwa masih terdapat 105 desa yang harus diselesaikan oleh pihak Kantor Pertanahan Kabupaten Klaten hingga bulan Desember tahun 2020. Berdasarkan wawancara dengan Kepala Subseksi Pengukuran Dasar dan Tematik Kantor Pertanahan Kabupaten Klaten, terdapat kendala-kendala dalam pelaksanaan INTIP antara lain: 1) pengumpulan data yang masih dilakukan dengan cara manual sehingga kegiatan kurang efisien dan optimal; 2) membutuhkan waktu yang cukup lama dalam pengolahan serta penyajian data hasil kegiatan INTIP, karena data tekstual dan spasial yang belum terintegrasi; 3) belum adanya keseragaman dalam proses pengumpulan data sehingga hasil pengumpulan data di lapangan tidak terstruktur dengan baik; 4) belum adanya manajemen data yang baik sehingga kesulitan dalam pembuatan pelaporan kegiatan; 5) belum adanya suatu sistem untuk mengontrol dan memantau progres kegiatan INTIP secara realtime. Permasalahan inilah yang menjadikan kendala serius bagi pihak Kantor Pertanahan Kabupaten Klaten untuk menyelesaikan banyaknya target yang belum terselesaikan.

Oleh karena itu, untuk efisiensi waktu terhadap pelaksanaan kegiatan ini dibutuhkan sebuah sistem informasi yang komprehensif dan dapat menjawab permasalahan dan kendala yang ada. Inovasi ini sangat dibutuhkan untuk mendukung percepatan pelayanan Kementerian ATR/BPN sehingga dapat terwujud Land Modern Office berbasis Teknologi Informasi (TI) yang sejalan dengan perkembangan industri 4.0. Menurut Budi Sutedjo Dharma Oetomo dalam (Puspitasari 2015) sistem informasi adalah suatu sistem yang dirancang untuk menyediakan informasi guna mendukung pengambilan keputusan pada kegiatan manajemen perencanaan, pemrakarsaan, pengorganisasian, dan pengendalian dalam suatu organisasi. Tujuan dari penelitian ini untuk membuat rancang bangun sistem informasi dalam membantu proses pengumpulan dan manajemen data tekstual dan spasial untuk kegiatan INTIP dan untuk mendeskripsikan manfaat hasil rancangan aplikasi sistem informasi bagi pengguna.

Pengujian keaslian penelitian dilakukan dengan cara membandingkan penelitian saat ini dengan penelitian sebelumnya yang sejenis. Pembandingan dilakukan dengan menganalisis temuan penelitian terdahulu dengan kemungkinan temuan dan model penelitian ini, perbandingan juga mengidentifikasi tujuan penelitian, metode analisis dan pengumpulan data, judul, nama peneliti, dan tahun penelitian. 
Penelitian sebelumnya dilakukan pada tahun 2016 oleh Hengki Saputro melalui skripsi Sekolah Tinggi Pertanahan Nasional dengan judul penelitian adalah "Pemanfaatan Data Penguasaan, Pemilikan, Penggunaan Dan Pemanfaatan Tanah (P4T) Untuk Rancang Bangun Aplikasi Sistem Informasi Pertanahan Desa (Studi di Desa Bangunjiwo, Kecamatan Kasihan, Kabupaten Bantul)". Hasil dari penelitian tersebut adalah berupa aplikasi yang dapat digunakan secara lokal dengan menampilkan informasi mengenai profil desa dan bidang tanah pada desa tersebut.

Penelitian selanjutnya dilakukan pada tahun 2017 oleh Agustinus Nurjati Cahyono melalui skripsi Sekolah Tinggi Pertanahan Nasional dengan judul penelitian adalah "Pembangunan Sistem Informasi Pertanahan Di Kelurahan Keraton Kecamatan Luwuk Kabupaten Banggai Provinsi Sulawesi Tengah". Hasil dari penelitian tersebut adalah berupa webgis yang dapat digunakan secara online, di mana webgis ini memberikan informasi mengenai Penguasaan, Pemilikan, Penggunaan Dan Pemanfaatan Tanah. Sistem informasi ini juga digunakan oleh kelurahan dalam melakukan pengecekan bidang tanah untuk pembuatan Surat Keterangan Penguasaan Tanah.

Penelitian selanjutnya dilakukan pada tahun 2018 oleh Reza Abdullah melalui skripsi Sekolah Tinggi Pertanahan Nasional dengan judul penelitian adalah "Perancangan Aplikasi Berbasis Android Dalam Pembuatan Peta Kerja Pendaftaran Tanah Sistematis Lengkap". Hasil dari penelitian tersebut adalah berupa Aplikasi ini dirancang berupa software prototype yang dibangun mulai dari analisis kebutuhan pengguna dan sistem, perencanaan metode koreksi data spasial, perancangan site map, basis data, relasi antar tabel serta desain interface, sehingga dapat digunakan dalam pembuatan peta kerja secara terintegrasi antara data spasial dan data yuridis sesuai kebutuhan PTSL.

Penelitian selanjutnya dilakukan pada tahun 2019 oleh Mardhiyah Hayati melalui skripsi Sekolah Tinggi Pertanahan Nasional dengan judul penelitian adalah "Rancang Bangun Sistem Informasi Penguasaan Pemilikan Penggunaan dan Pemanfaatan Tanah (Studi di Kantor Pertanahan Kota Bukittinggi, Provinsi Sumatera Barat)". Hasil dari penelitian tersebut adalah berupa Sistem Informasi Pertanahan ini mampu melakukan analisis data secara langsung dari data yang telah diinput ke dalam basis data, dan mampu mencari data pemilikan tanah berdasarkan NIK dapat digunakan sebagai alat monitoring dan evaluasi tanah objek landreform.

Penelitian lain dilakukan pada tahun 2019 oleh Abinowo melalui skripsi Sekolah Tinggi Pertanahan Nasional dengan judul penelitian adalah "Rancang Bangun Aplikasi Pengintegrasian Data Fisik dan Data Yuridis Dalam Kegiatan Pendaftaran Tanah Sistematis Lengkap (Studi di Kantor Pertanahan Kabupaten Bantul)". Hasil dari penelitian tersebut 
adalah berupa Aplikasi untuk membantu proses integrasi data fisik dan data yuridis. Digunakan untuk membantu panitia adjudikasi PTSL dalam mengetahui capaian dari masing-masing satgas dan melihat laporan setiap saat karena data yang diinput ke dalam sistem secara langsung dapat terlihat dengan baik secara visual untuk dijadikan pertimbangan pengambilan keputusan.

Beberapa persamaan antara penelitian saat ini dengan penelitian terdahulu terkait dengan analisis data dan metode penelitian. Adapun perbedaan penelitian ini dengan penelitian terdahulu terletak pada waktu, lokasi, tujuan, dan temuan penelitian yang diharapkan. Kebaruan penelitian dilakukan melalui judul "Rancang Bangun Sistem Informasi Collecting dan Plotting Pertanahan (Si-Copilot) Untuk Kegiatan Inventarisasi Tanah Instansi Pemerintah di Kantor Pertanahan Kabupaten Klaten. Peneliti lebih memfokuskan pada kebutuhan kantor pertanahan mengenai informasi yang akan diperoleh, serta mempermudah pengumpulan dan pengolahan data hasil survei INTIP dan manajemen penyimpanan datanya. Kelima penelitian tersebut menyajikan informasi yang berbeda-beda. Begitu juga dalam penelitian ini, informasi yang disajikan adalah penyajian data persebaran hasil kegiatan INTIP, serta menghasilkan output berupa titik berbentuk (.shp) yang sudah memiliki informasi di dalamnya kemudian dilakukan pengolahan data untuk pembuatan peta persebaran tanah instansi pemerintah.

Secara substantif terdapat perbedaan penelitian ini dengan penelitian terdahulu, perbedaan tersebut pada bahasa pemrograman, perangkat lunak pengelola basis data, dan framework. Penelitian yang telah dilakukan sebelumnya di antaranya menggunakan framework HTML, Bootstrap. Bahasa pemrograman yang digunakan PHP (Hypertext Prepocessor), dan software pengelolaan basis data yang digunakan yaitu MySQL. Sedangkan penelitian ini menggunakan framework Ruby On Rails (RoR), peneliti menggunakan bahasa pemrograman Ruby dan pada pengelolaan basis data menggunakan PostgreSQL.

\section{B. Metode Penelitian}

Penelitian ini merupakan penelitian research and development dengan membuat Sistem Informasi Collecting dan Plotting Pertanahan (Si-Copilot) untuk digunakan dalam kegiatan Inventarisasi Tanah Instansi Pemerintah. Lokasi penelitian berada di Kantor Pertanahan Kabupaten Klaten. Data primer pada penelitian ini dibutuhkan untuk memudahkan pekerjaan INTIP dan menganalisis kebutuhan pengguna dan analisis kebutuhan sistem secara faktual, sehingga menjadi lebih cepat dan terstruktur. Adapun data sekunder yang digunakan meliputi: (1) peta Pendaftaran (2) lampiran Juknis No.5/Juknis600.TP.03.01/XII/2019 tentang Inventarisasi Tanah Instansi Pemerintah (INTIP) (3) basemap 
Google Maps, Basemap Google Satellite, Basemap Google Satellite Hybrid, Google Street View, Basemap Road Maps yang berasal dari fitur Google (4) format formulir daftar isian INTIP berasal dari petunjuk teknis tahun 2019. Teknik pengumpulan data dilakukan melalui wawancara, studi dokumen, dan observasi lapang.

Data yang dikumpulkan berupa data kualitatif yang terdiri dari dua yaitu data primer dan data sekunder. Kedua data tersebut dianalisis secara deskriptif yaitu menganalisis data dengan cara memaparkan serta menguraikan dengan jelas proses perancangan sistem informasi dan cara kerja sistem informasi yang dibangun. Setelah itu dilakukan pengujian, hasil yang diperoleh digambarkan kegunaan serta manfaat dari sistem informasi untuk pelaksanaan kegiatan INTIP. Langkah-langkah penelitian melalui enam tahapan seperti pada gambar berikut ini:

Gambar 1. Bagan Alir Langkah-Langkah Penelitian

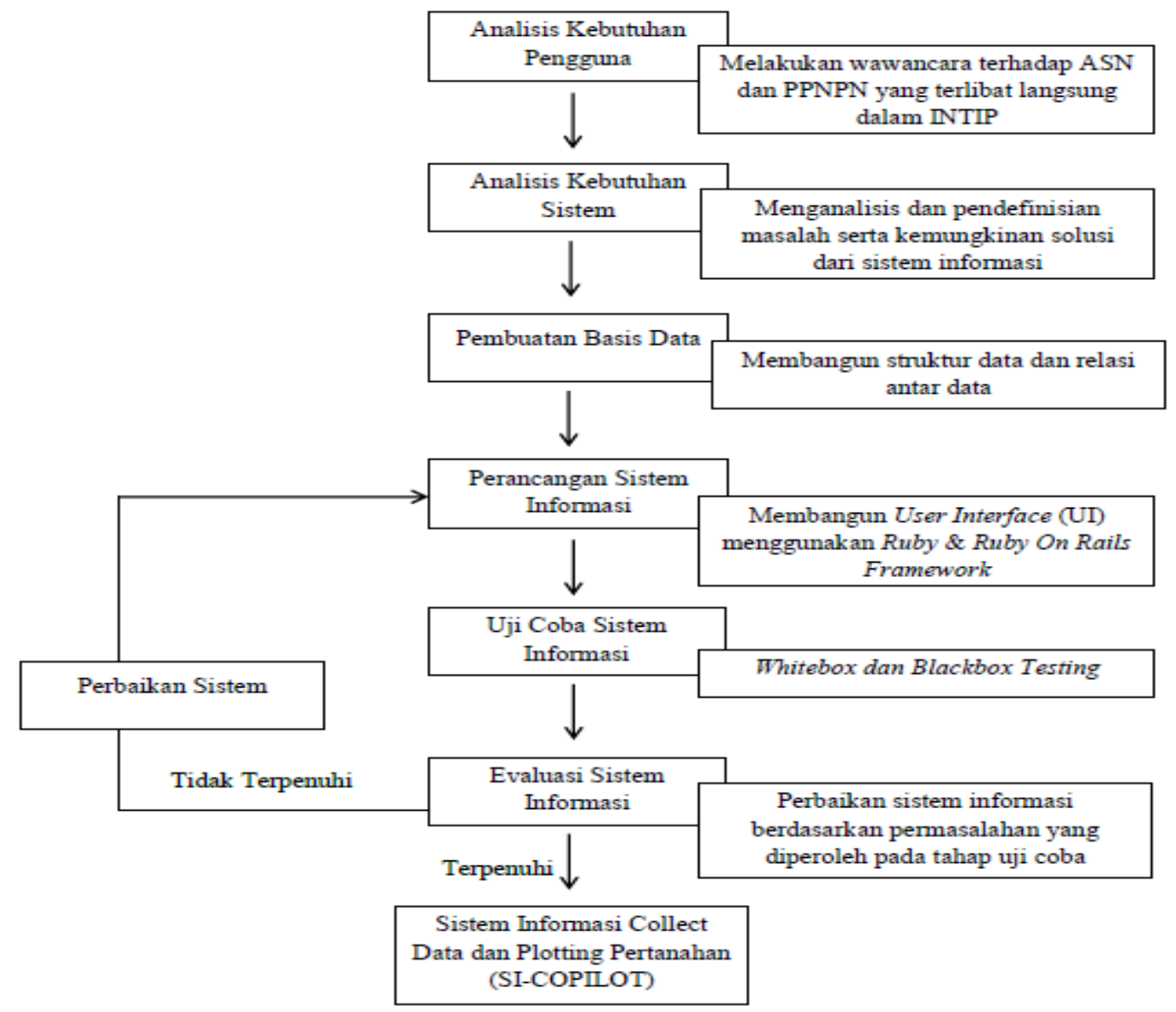

Sumber: Dokumen Peneliti, Mei 2021

\section{Pembangunan Sistem Informasi Collecting dan Plotting Pertanahan (Si-Copilot)}

1. Analisis Kebutuhan Pengguna

Analisis kebutuhan pengguna diperoleh dengan cara wawancara kepada beberapa informan, terutama yang terlibat langsung dalam pelaksanaan kegiatan INTIP. Wawancara 
dilakukan dengan Kepala Seksi Pengadaan Tanah dan Pengembangan, Kepala Seksi Survei Pengukuran dan Pemetaan, Kelompok Jabatan Fungsional pada Seksi Survei Pengukuran dan Pemetaan dan Tim Pelaksana Kegiatan INTIP yaitu 1 (satu) orang ASN dan 1 (satu) orang PPNPN.

Berdasarkan hasil wawancara yang dilakukan, permasalahan dan kendala yang ada di Kantor Pertanahan Kabupaten Klaten dapat dijabarkan analisis kebutuhan pengguna, sesuai dengan analisis kebutuhan penggunaan di bawah ini:

Tabel 1. Analisis Kebutuhan Pengguna

\begin{tabular}{|c|c|c|c|}
\hline No & Permasalahan & Kebutuhan & $\begin{array}{l}\text { Jenis } \\
\text { Data }\end{array}$ \\
\hline 1 & $\begin{array}{l}\text { Pelaksanaan pengumpulan data } \\
\text { tekstual dan spasial dilakukan secara } \\
\text { manual menggunakan hardcopy, } \\
\text { sehingga memerlukan } 2 \text { (dua) kali } \\
\text { alokasi waktu, yaitu pelaksanaan } \\
\text { survei dengan pengisian daftar isian } \\
\text { INTIP, kemudian data tekstual } \\
\text { dituangkan dalam microsoft excel dan } \\
\text { data spasial dilakukan input pada } \\
\text { software ArcGIS yang kemudian } \\
\text { dilakukan join terhadap kedua data } \\
\text { tersebut }\end{array}$ & $\begin{array}{l}\text { - Sistem aplikasi yang dapat } \\
\text { membantu dalam efisiensi } \\
\text { waktu dalam pelaksanaan } \\
\text { pengumpulan data INTIP } \\
\text { - Sistem aplikasi dapat } \\
\text { melakukan pick point di } \\
\text { lapangan maupun } \\
\text { interpretasi dengan } \\
\text { menggunakan Citra Google } \\
\text { Satellite dapat } \\
\text { - Sistem aplikasi dan } \\
\text { menyederhanakan form isian }\end{array}$ & $\begin{array}{l}\text { Data } \\
\text { Tekstual } \\
\text { dan } \\
\text { Data } \\
\text { Spasial }\end{array}$ \\
\hline 2 & $\begin{array}{l}\text { Pengumpulan data tekstual dan } \\
\text { spasial dibedakan menjadi dua } \\
\text { formulir yang berbeda dan dirasa } \\
\text { kurang efisien }\end{array}$ & $\begin{array}{l}\text { survei INTIP menjadi lebih } \\
\text { ringkas dan mudah dipahami } \\
\text { - Sistem aplikasi dapat } \\
\text { melakukan import daftar }\end{array}$ & \\
\hline 3 & $\begin{array}{l}\text { Pengumpulan data tekstual dan } \\
\text { spasial menggunakan hardcopy } \\
\text { seringkali terdapat kesalahan } \\
\text { penulisan dalam pengambilan data di } \\
\text { lapangan }\end{array}$ & $\begin{array}{l}\text { nominatif dalam bentuk excel } \\
\text { yang sebelumnya sudah } \\
\text { disusun ataupun dapat } \\
\text { melakukan secara satu per } \\
\text { satu }\end{array}$ & \\
\hline 4 & $\begin{array}{l}\text { Penyimpanan data hasil INTIP masih } \\
\text { berupa hardcopy sehingga mengalami } \\
\text { kesulitan pencarian jika data tersebut } \\
\text { dibutuhkan pada tahun mendatang }\end{array}$ & $\begin{array}{l}\text { - Sistem aplikasi mampu untuk } \\
\text { menyimpan data kegiatan } \\
\text { INTIP sehingga memudahkan } \\
\text { dalam manajemen data } \\
\text { apabila dibutuhkan pada } \\
\text { tahun mendatang }\end{array}$ & \\
\hline 5 & $\begin{array}{l}\text { Pengolahan data spasial seharusnya } \\
\text { dioverlay dengan data tekstual, } \\
\text { sehingga adanya sinkronisasi antara } \\
\text { data spasial dengan data tekstual. }\end{array}$ & $\begin{array}{l}\text { - Sistem aplikasi mampu } \\
\text { melakukan export data } \\
\text { sebagai output berupa daftar } \\
\text { nominatif lengkap }{ }^{*} \times l s \text {, titik } \\
\text { koordinat bidang tanah*shp } \\
\text { dan sket bidang tanah }{ }^{*} \text { pdf }\end{array}$ & $\begin{array}{l}\text { Data } \\
\text { Tekstual } \\
\text { dan } \\
\text { Data } \\
\text { Spasial }\end{array}$ \\
\hline
\end{tabular}


6 Kesulitan dalam melakukan koordinasi dan monitoring dalam satu tim

7 Banyaknya target yang diberikan sehingga setiap tim mengalami kesulitan dalam melakukan manajemen data, dan pelaporan kegiatan

8 Monitoring kegiatan INTIP tidak dapat dilakukan secara realtime dan harus menunggu pelaporan dari masing-masing tim

- Sistem aplikasi hanya dapat Data digunakan oleh pengguna Tekstual yang sudah ditentukan oleh kantor pertanahan

- Sistem aplikasi dapat memonitoring kegiatan yang dilakukan oleh sesama pengguna dalam satu wilayah kerja

- Sistem aplikasi dapat melakukan monitoring untuk satu tim dan dapat melakukan data sebagai pelaporan kegiatan.

- Sistem aplikasi dapat memonitoring seluruh kegiatan INTIP yang dilakukan oleh masingmasing tim

Sumber: Pengolahan Data Primer, Mei 2021

\section{Analisis Kebutuhan Sistem}

Analisis kebutuhan sistem bertujuan untuk menjawab analisis kebutuhan pengguna. Analisis kebutuhan sistem berhubungan dengan kemampuan teknologi aplikasi yang dibangun. Berdasarkan analisis kebutuhan pengguna, aplikasi yang dibangun menyediakan form registrasi untuk memperoleh username dan password. Dengan username dan password ini, dapat mengakses informasi sesuai dengan hak akses yang dimiliki. Aplikasi yang dibangun memiliki 3 (tiga) tingkatan hak akses di antaranya:

a. Superadmin, merupakan tingkat pertama hak akses yang memiliki keseluruhan hak akses. Pengguna ini mampu melakukan CRUD (Create, Read, Update, dan Delete). Tidak ada pembatasan pada pengguna ini, seperti pengelolaan pengguna lainnya.

b. Admin, merupakan tingkat kedua hak akses. Pengguna dengan hak akses ini juga dapat melakukan CRUD, tetapi dibatasi dengan pengelolaan pengguna lainnya.

c. User, merupakan tingkat ketiga hak akses, di mana pengguna dengan hak akses ini hanya dapat melakukan create dan read saja. Hak akses ini bertujuan agar masyarakat mampu melakuan pengentrian bidang tanah yang dia miliki sendiri.

Untuk spesifikasi kebutuhan sistem dapat diuraikan sebagai berikut: 
a. Sistem yang mampu melakukan percepatan proses pengumpulan dan pengolahan data INTIP, hingga dapat menyajikan daftar isian sesuai dengan Petunjuk Teknis Pelaksanaan INTIP di kantor oertanahan.

b. Sistem yang mampu menyediakan fitur import dan export data. Jika data telah diisikan dengan format excel, dapat diinput kedalam aplikasi. Setelah pekerjaan telah dilaksanakan data tersebut dapat diunduh melalui aplikasi.

c. Sistem yang mampu melakukan pick point di lapangan dengan fitur citra satelit dari Google, bertujuan untuk memudahkan dalam melakukan pengumpulan data di lapangan.

3. Pembuatan Basis Data

a. Tahap Persiapan

Pada tahapan ini peneliti mengidentifikasi kebutuhan perangkat keras (hardware) dan perangkat lunak (software) untuk pembuatan Basis Data dari Sistem Informasi Collecting dan Plotting Pertanahan.

1) Perangkat Keras (Hardware): Satu unit laptop dengan RAM 4 sampai dengan RAM 16 GB.

2) Perangkat Lunak (Software)

a) Sistem operasi windows 7 pada laptop;

b) Ruby dan CSS sebagai bahasa pemrograman pada perancangan aplikasi;

c) Ruby on rails sebagai web framework pada perancangan aplikasi;

d) Notepad++ dan VSCode untuk pembuatan script dalam perancangan aplikasi;

e) PostgreSQL sebagai pengelola basis data aplikasi yang open source;

b. Tahap Pelaksanaan

Perancangan basis data sistem aplikasi memerlukan 13 tabel yang terhubung satu sama lain, tabel tersebut berisikan informasi terkait dengan kebutuhan data yang dimasukkan oleh pengguna dalam hal ini adalah pelaksana kegiatan INTIP.

4. Perancangan Sistem Informasi

a. Model UML Sistem Informasi Collecting dan Plotting Pertanahan (Si-Copilot)

Menurut Sugiarti (2016) dalam merancang sebuah sistem atau perangkat lunak diperlukan sebuah metode atau pendekatan untuk menjabarkan spesifikasi standar yang akan dibangun, seperti Unified Modelling Language (UML). UML dapat pula disebut sebagai spesifikasi standar untuk spesifikasi dan dokumentasi dalam membangun perangkat lunak. Alat bantu yang digunakan dalam perancangan berbasis UML antara lain:

1) Activity Diagram 
Menurut Sukamto dan Shalahuddin (2013), activity diagram menggambarkan aliran kerja sebuah sistem yang ada pada sistem informasi. Pemodelan ini menggambarkan bagaimana alir kerja dalam sistem berjalan, decision yang mungkin terjadi, dan bagaimana sistem berakhir. Bentuk Activity Diagram dari Sistem Informasi Collecting dan Plotting Pertanahan dibagi menjadi tiga tingkatan hak akses yang salah satunya seperti pada gambar berikut:

Gambar 2. Diagram Activity Super Admin

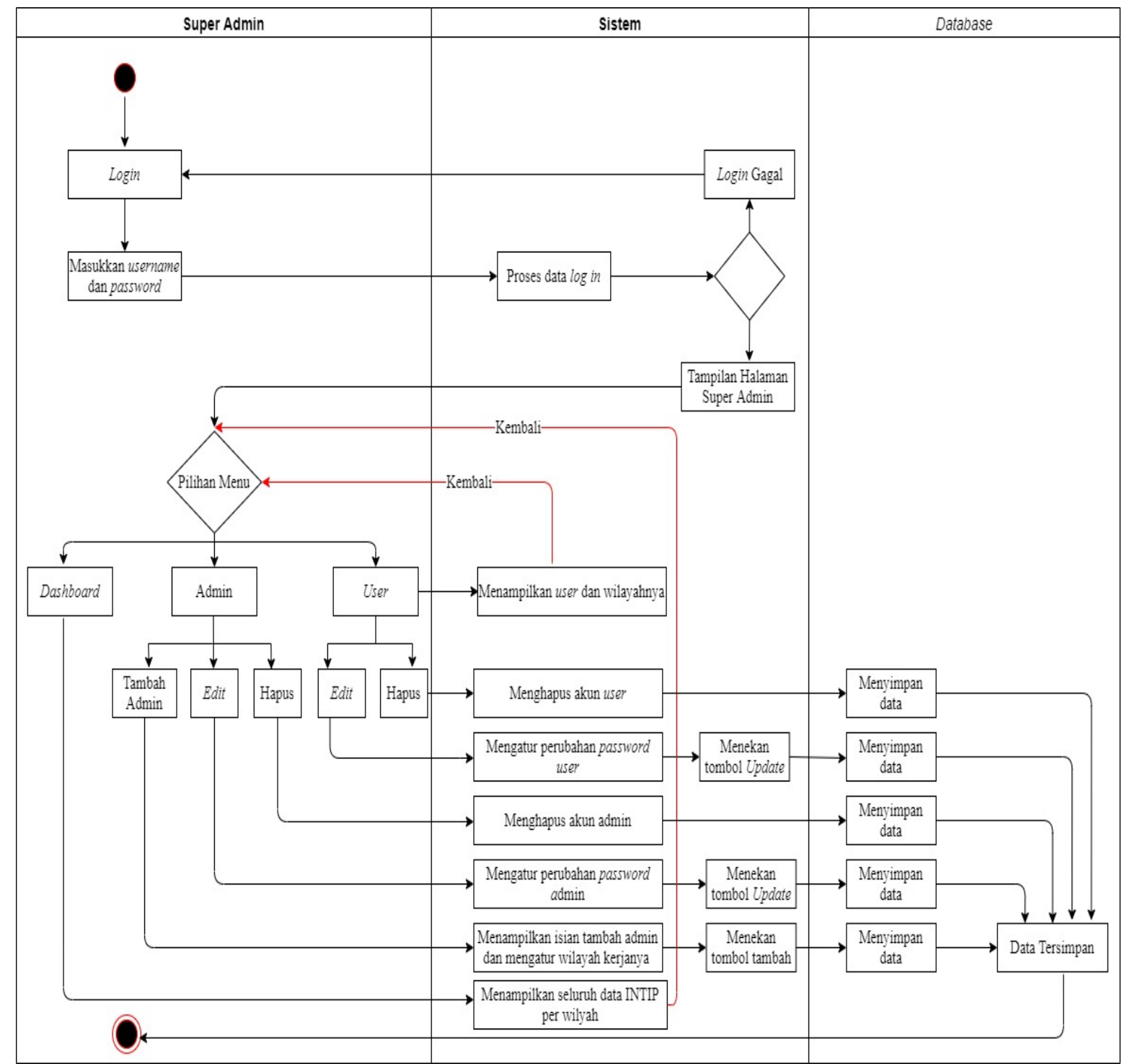

Sumber: Olahan Data Peneliti, Mei 2021

\section{2) Use Case}

Di mana pemodelan berdasarkan kelakuan (behavior) sistem informasi yang akan dibuat, selain itu juga digunakan untuk mengetahui fungsi yang ada di dalam sistem informasi dan siapa saja yang berhak menggunakan fungsi-fungsi tersebut (Sugiarti 2016, 
41). Bentuk use case dari Sistem Informasi Collecting dan Plotting Pertanahan seperti pada gambar berikut:

Gambar 3. Use Case Diagram

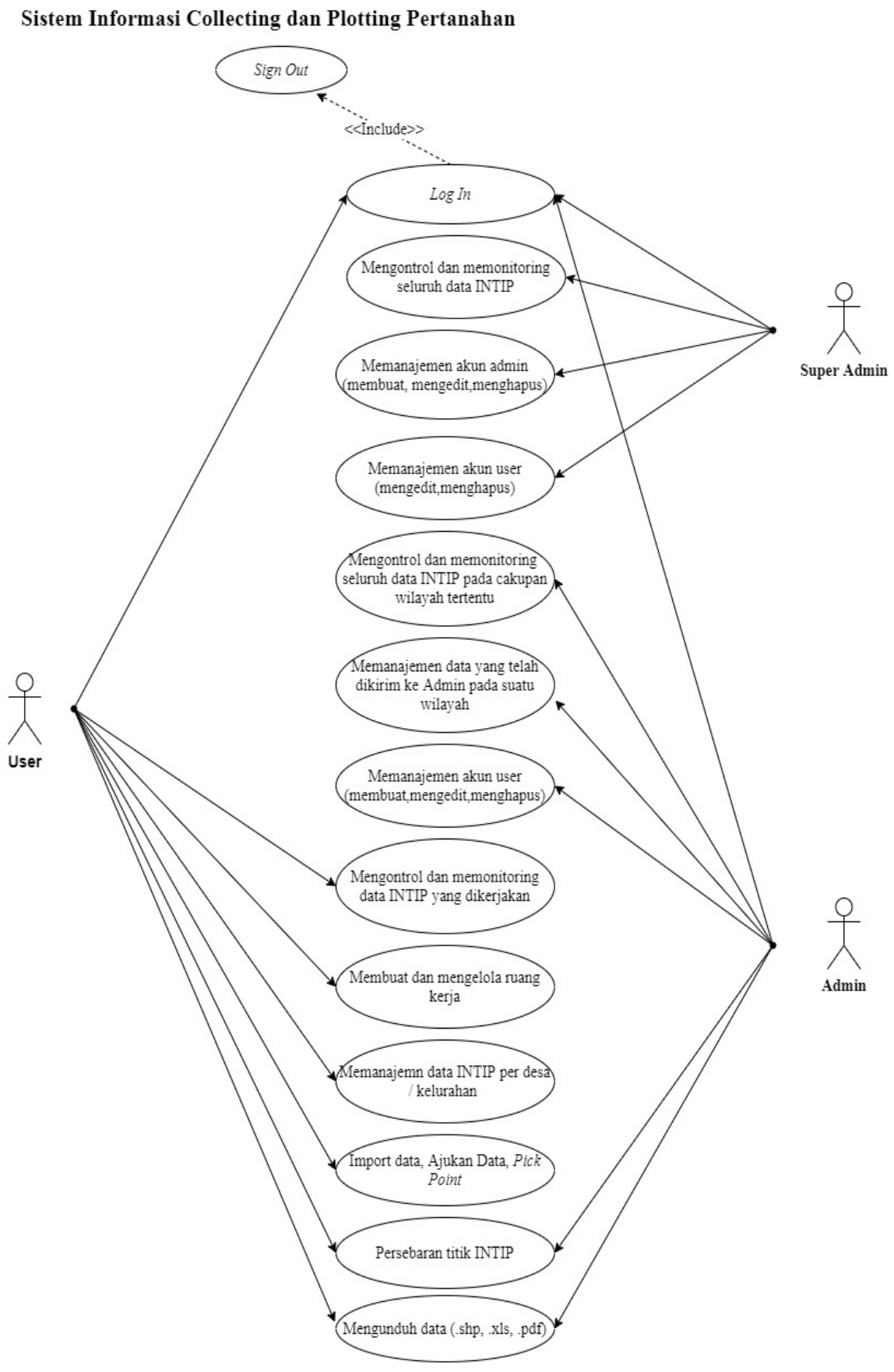

Sumber: Olahan Data Peneliti, Mei 2021

\section{3) Class Diagram}

Merupakan diagram yang menghubungkan antar kelas dan deskripsi rinci setiap kelas dalam model desain sistem, dan menunjukkan aturan dan tanggung jawab entitas yang menentukan perilaku sistem (Sugiarti 2016, 57). 


\section{4) User Interface}

User interface merupakan tahapan perancangan sistem yang menghubungkan antara pengguna dengan database. Untuk memudahkan pemahaman desain interface pada aplikasi yang dirancang, maka pada penelitian ini peneliti membagi desain interface menjadi tiga berdasarkan tipe hak akses penggunanya, seperti: super admin, admin, dan user.

5) Menu Super Admin

a) Halaman Dashboard: saat pertama kali mengakses halaman super admin maka yang muncul adalah tampilan dashboard. Pada tampilan ini muncul seluruh rekapitulasi pekerjaan berdasarkan wilayah dari seluruh pengguna sistem informasi.

b) Halaman Admin: halaman admin dari sistem informasi berguna untuk memanajemen, menambah dan mengatur wilayah kerja admin. Pada tampilan tersebut terdapat menu tambah admin untuk menambah admin, menu edit untuk mengubah akun tersebut dan hapus untuk menghapus akun tersebut.

c) Halaman User: halaman user dari sistem informasi berguna untuk memanajemen, dan mengontrol seluruh user yang menggunakan sistem informasi. Pada menu ini super admin dapat melakukan edit dan juga hapus terhadap akun user. Berikut gambar salah satu tampilan dari super admin:

Gambar 4. Tampilan Menu Super Admin
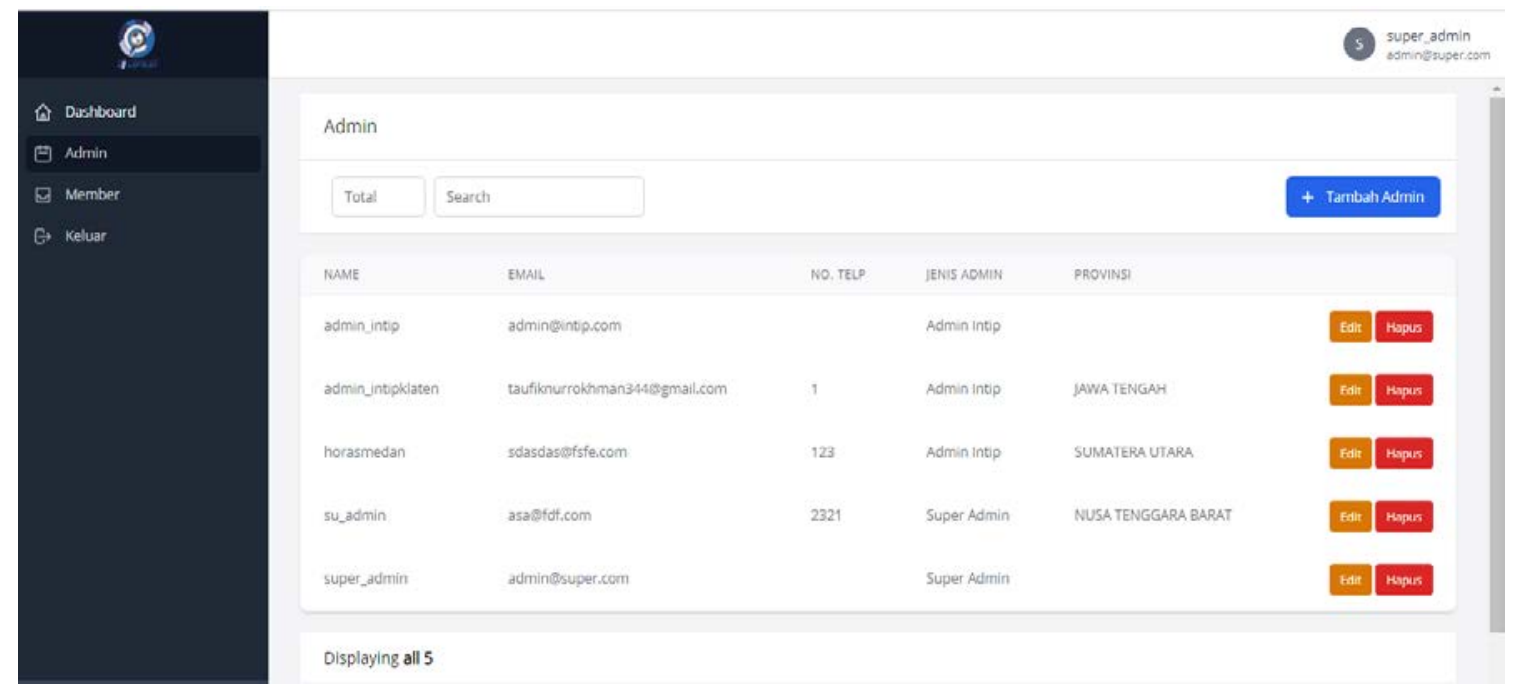

Sumber: Olahan Data Peneliti, Mei 2021

6) Menu Admin

a) Halaman Dashboard: pada tampilan ini muncul rekapitulasi pekerjaan yang dilakukan oleh user berdasarkan lokasi wilayah kerja admin. Menu ini juga 
berfungsi untuk mengontrol dan memonitoring kegiatan INTIP dari masingmasing pengguna sistem informasi.

b) Halaman User: halaman user digunakan untuk memanajemen akun user meliputi membuat, mengedit, dan menghapus. Setelah itu terdapat pilihan menu diantaranya; menu tambah untuk menambah akun user, edit untuk merubah password dari akun tersebut dan hapus untuk menghapus akun user tersebut.

c) Halaman Inventarisasi Tanah Instansi Pemerintah: halaman ini digunakan untuk memanajemen data yang telah dikirimkan oleh user kepada admin. Setelah itu, muncul rekapitulasi pekerjaan INTIP berdasarkan user dan terdapat pilihan menu detail. Pada halaman ini menampilkan workspace dari user. Apabila ingin menampilkan lembar kerja yang telah dilakukan oleh user tersebut maka klik pada nama workspace tersebut. Pada tampilan ini terdapat menu untuk mengunduh hasil pekerjaan yang telah dilakukan. Untuk mengunduhnya, pilih menu download. Data hasil unduhan tersebut diantaranya; data persebaran titik bidang tanah berbentuk (.shp), daftar isian INTIP berbentuk (.xls) dan sket bidang tanah untuk mempermudah pengolahan data berbentuk (.pdf). Berikut gambar salah satu tampilan dari admin:

Gambar 5. Tampilan Menu Admin

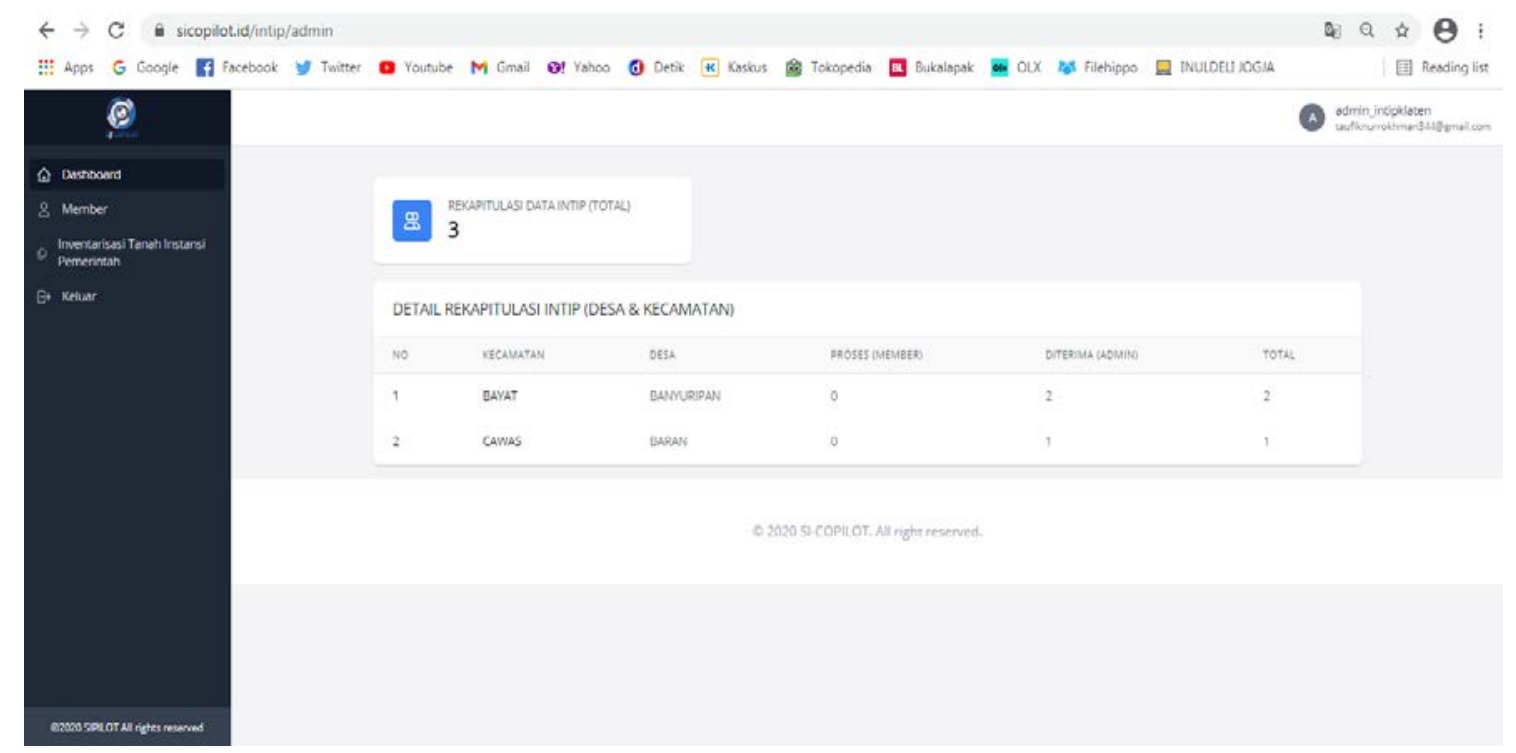

Sumber: Olahan Data Peneliti, Mei 2021

7) Tampilan Menu User

a) Halaman Dashboard: pada tampilan ini muncul rekapitulasi pekerjaan yang telah dilakukan. Menu ini juga berfungsi untuk mengontrol dan memonitoring atas data INTIP yang dikerjakan apakah sudah terkirim kepada admin atau belum. 
Selain itu juga terdapat grafik batang yang menjelaskan kinerja yang telah dilakukan oleh user tersebut pada setiap bulannya.

b) Halaman Inventarisasi Tanah Instansi Pemerintah: pada halaman ini digunakan untuk membuat dan mengelola ruang kerja yanag dilakukan oleh user. Setelah itu muncul beberapa menu di antaranya; menu buat workspace untuk membuat dan mengatur lembar kerja, menu detail untuk mengetahui lokasi yang dikerjakan pada workspace, dan menu hapus untuk menghapus workspace tersebut.

c) Halaman Ajukan Data: menu ajukan untuk menginputkan data secara sporadik (satu per satu).

d) Halaman Import: menu import untuk melakukan input data secara sistematis (memasukkan daftar nominatif secara bersamaan).

e) Halaman Laporan INTIP Lengkap: data yang sudah dikirimkan ke Admin maka muncul pada Menu Laporan Permohonan INTIP Lengkap. Setelah itu untuk melakukan unduh data hasil pekerjaan yang telah dilakukan dan untuk pembuatan pelaporannya maka klik pada nama workspace tersebut. Kemudian untuk mengunduh data hasil pekerjaan yang telah dilakukan pilih menu download. Data hasil unduhan tersebut di antaranya; data persebaran titik bidang tanah berbentuk (.shp), daftar isian INTIP berbentuk (.xls) dan sket bidang tanah untuk mempermudah pengolahan data berbentuk (.pdf). Berikut gambar salah satu tampilan dari user:

Gambar 6. Tampilan Menu User

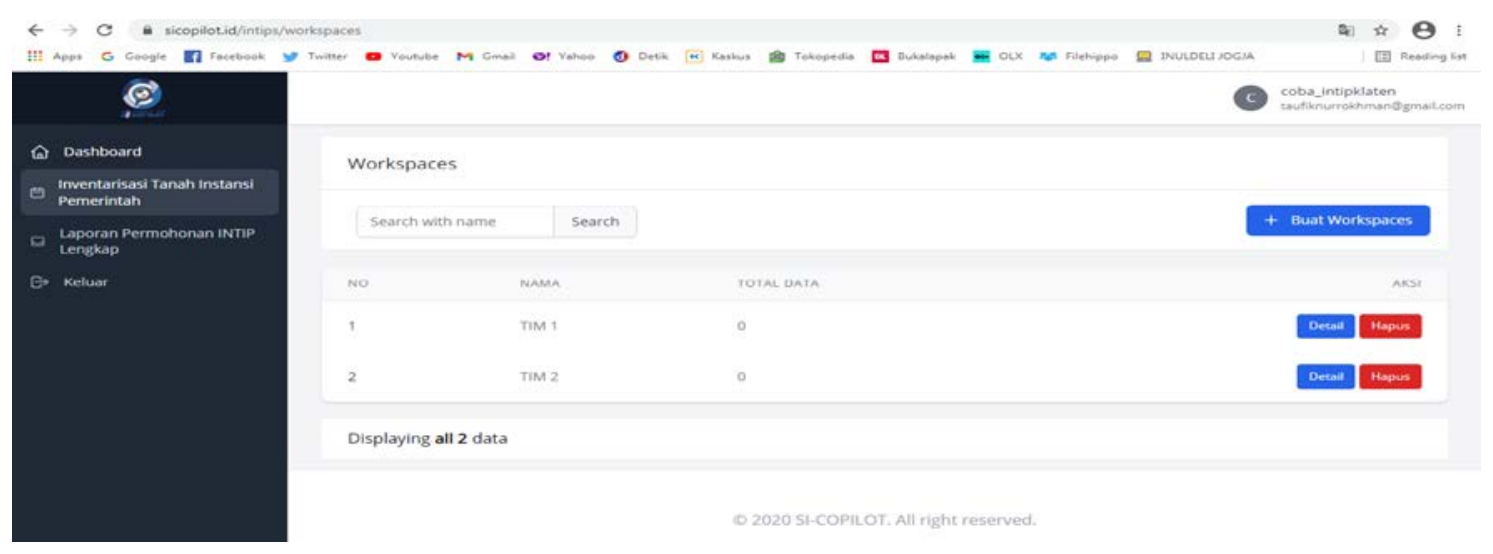

Sumber: Olahan Data Peneliti, Mei 2021

8. Uji Coba Sistem Informasi

a.Whitebox testing

Menurut Rosa dan Shalahuddin (2011), white box testing adalah salah satu cara untuk menguji suatu aplikasi atau software dengan cara melihat modul untuk dapat meneliti dan 
menganalisis kode dari program yang dibuat apabila terdapat kesalahan. Kalau modul yang telah dan sudah dihasilkan berupa output yang tidak sesuai dengan yang diharapkan maka akan dikompilasi ulang dan dicek kembali kode-kode tersebut hingga sesuai dengan yang diharapkan (Nidhra and Dondetti, 2012).

Pada saat melakukan pengujian terhadap sistem informasi pertanahan, harus dipastikan terlebih dahulu bahwa seluruh kode program diperiksa dan dihilangkan kesalahannya. Metode inilah yang dikenal dengan White Box Testing. Pada dasarnya metode White Box Testing sudah dilakukan pada saat perancangan sistem informasi pertanahan khususnya dalam penulisan script pemrograman. Script pemrograman dapat dengan mudah dideteksi apabila terdapat kesalahan dalam perancangan. Setelah dilakukan testing, pada perancangan sistem informasi collecting dan plotting pertanahan tidak terdapat bug (kesalahan) pada sistem pemrogramannya.

\section{b. Blackbox testing}

Langkah selanjutnya yaitu melakukan pengujian dengan metode black box testing yaitu dengan uji coba dan sosialisasi kepada responden. Proses uji coba dilakukan di Kantor Pertanahan Kabupaten Klaten, dengan kelompok uji coba ASN yang terlibat dalam pengumpulan dan pengolahan data INTIP. Uji coba dilakukan dengan terlebih dahulu mensosialisasikan bagaimana cara menggunakan dan memproses data di Sistem Informasi Collecting dan Plotting Pertanahan (Si-Copilot). Setelah sosialisasi dilakukan, kelompok uji coba diberikan kesempatan untuk mencoba sendiri sistem informasi tersebut, di mana tujuan akhir adalah dengan pemberian kuesioner tertutup penilaian dan saran tentang aplikasi.

Hasil dari permintaan pengisian kuesioner tertutup dari beberapa responden, sebagai mana pada Tabel 2. Hasil ini kemudian diolah dengan menggunakan skala likert untuk penarikan kesimpulannya.

Tabel 2. Hasil Kuisioner Pengujian Sistem Informasi

\begin{tabular}{|c|c|c|c|c|c|c|c|c|c|c|c|}
\hline \multirow[t]{2}{*}{ No } & \multirow[t]{2}{*}{ Pertanyaan } & \multicolumn{10}{|c|}{ Responden } \\
\hline & & 1 & 2 & 3 & 4 & 5 & 6 & 7 & 8 & 9 & 10 \\
\hline 1 & Tampilan & SB & SB & SB & B & SB & SB & B & B & B & SB \\
\hline 2 & $\begin{array}{l}\text { Menu-menu yang } \\
\text { dapat dipahami }\end{array}$ & B & B & B & $\mathrm{C}$ & $\mathrm{SC}$ & B & SB & B & B & B \\
\hline 3 & Memudahkan & SB & B & SC & B & B & SC & $\mathrm{C}$ & B & SB & B \\
\hline 4 & $\begin{array}{l}\text { Percepatan } \\
\text { pengumpulan } \\
\text { data }\end{array}$ & SC & SC & B & SB & B & B & SB & SB & SC & SB \\
\hline
\end{tabular}




\begin{tabular}{llllllllllll}
\hline 5 & $\begin{array}{l}\text { Percepatan } \\
\text { pengolahan data }\end{array}$ & B & B & SC & SB & SB & SC & C & B & SB & SB \\
\hline 6 & $\begin{array}{l}\text { Penyajian data } \\
\text { cepat }\end{array}$ & C & C & SC & B & C & SB & SB & SB & B & B \\
\hline 7 & $\begin{array}{l}\text { Mudah } \\
\text { dioperasikan }\end{array}$ & SB & SB & B & SC & SC & SC & C & B & SC & B \\
\hline 8 & $\begin{array}{l}\text { Memberi manfaat } \\
\text { bagi kantor } \\
\text { pertanahan }\end{array}$ & SB & SB & SB & B & B & B & B & SB & B & B \\
\hline
\end{tabular}

Sumber: Pengolahan Data Primer 2021

Hasil penilaian responden berada pada rentang cukup hingga sangat baik, tidak terdapat penilaian yang menyatakan kurang. Berdasarkan data tersebut, maka dapat dianalisis sebagaimana Tabel 3.

Tabel 3. Analisis Skala Likert Uji Coba dan Evaluasi Sistem Informasi Collecting dan Plotting Pertanahan

\begin{tabular}{|c|c|c|c|c|c|c|c|c|}
\hline \multirow[b]{2}{*}{ Responden } & \multicolumn{8}{|c|}{ Nomor Pertanyaan } \\
\hline & 1 & 2 & 3 & 4 & 5 & 6 & 7 & 8 \\
\hline R1 & 5 & 4 & 5 & 3 & 4 & 2 & 5 & 5 \\
\hline $\mathrm{R} 2$ & 5 & 4 & 4 & 3 & 4 & 2 & 5 & 5 \\
\hline $\mathrm{R} 3$ & 5 & 4 & 3 & 4 & 3 & 3 & 4 & 5 \\
\hline $\mathrm{R} 4$ & 4 & 2 & 4 & 5 & 5 & 4 & 3 & 4 \\
\hline R5 & 5 & 3 & 4 & 4 & 5 & 2 & 3 & 4 \\
\hline R6 & 5 & 4 & 3 & 4 & 3 & 5 & 3 & 4 \\
\hline R7 & 4 & 5 & 2 & 5 & 2 & 5 & 2 & 4 \\
\hline $\mathrm{R} 8$ & 4 & 4 & 4 & 5 & 4 & 5 & 4 & 5 \\
\hline R9 & 4 & 4 & 5 & 3 & 5 & 4 & 3 & 4 \\
\hline R10 & 5 & 4 & 4 & 5 & 5 & 4 & 4 & 4 \\
\hline Total Nilai & 46 & 38 & 38 & 41 & 40 & 36 & 36 & 44 \\
\hline Index $(\%)$ & 92,00 & 76,00 & 76,00 & 82,00 & 80,00 & 72,00 & 72,00 & 88,00 \\
\hline Total & \multicolumn{8}{|c|}{$638,00 \%$} \\
\hline Rata-rata & \multicolumn{8}{|c|}{$79,75 \%$} \\
\hline
\end{tabular}

Sumber: Pengolahan Data Primer 2021

9. Masukan dan Perbaikan Sistem Informasi

Pelaksanaan perbaikan Sistem Informasi Collecting dan Plotting Pertanahan dilakukan berdasarkan saran dan masukan yang diperoleh dari hasil wawancara uji coba aplikasi di 
Kantor Pertanahan Kabupaten Klaten. Dalam proses perbaikan aplikasi Sistem Informasi ini, tidak semua dapat dilaksanakan oleh peneliti. Perbaikan yang telah dilakukan oleh peneliti dapat dilihat pada Tabel 4 .

Tabel 4. Masukan yang dilakukan perbaikan

\begin{tabular}{llc}
\hline No & \multicolumn{1}{c}{ Masukan } & $\begin{array}{c}\text { Tindakan } \\
\text { Perbaikan }\end{array}$ \\
\hline 1. & Menampilkan titik persebaran INTIP & $\sqrt{ }$ \\
\hline 2. & Penambahan menu percetakan peta pada aplikasi & - \\
\hline 3. & Penambahan menu import (.shp) & - \\
\hline 4. & Penambahan menu kanvas & $\sqrt{ }$ \\
\hline 5. & Penambahan menu upload sket bidang tanah atau alas hak bagi & $\sqrt{ }$ \\
\hline 6. & Hasil koordinat export (.shp) TM3 & $\sqrt{ }$ \\
\hline 7. & $\begin{array}{l}\text { Pengaturan pada sistem agar dapat digunakan seluruh Kantor } \\
\text { Pertanahan di Indonesia untuk kegiatan INTIP. }\end{array}$ & - \\
\hline 8. & $\begin{array}{l}\text { Penambahan untuk menu survei bebas sehingga aplikasi dapat } \\
\text { digunakan dalam hal pengumpulan data selain kegiatan INTIP }\end{array}$ & $\sqrt{ }$ \\
\hline 9. & $\begin{array}{l}\text { User dapat membuat dan mengelola workspace sehingga } \\
\text { pekerjaan dapat terstruktur dengan baik }\end{array}$ & $\sqrt{ }$ \\
\hline 10. & $\begin{array}{l}\text { Dashboard pada superadmin dapat melihat seluruh data yang } \\
\text { masuk kedalam sistem dan terstruktur dengan baik setiap } \\
\text { daerahnya }\end{array}$ & \\
\hline
\end{tabular}

Sumber: Pengolahan Data Primer 2021

Berdasarkan Tabel 4, dari sepuluh masukan yang diberikan terdapat enam masukan yang ditindaklanjuti oleh peneliti dan empat masukan tidak ditindaklanjuti. Dapat dilihat bahwa perbaikan dilakukan pada masukan pertama, ke-5, ke-6, ke-7, ke-9, dan ke-10. Untuk masukan ke-2, ke-3 dan ke-4 tidak dilakukan karena membutuhkan waktu yang cukup lama untuk looping data pada server, sehingga memperberat kerja dari sistem informasi. Sedangkan untuk masukan yang ke-8, membutuhkan perubahan pada flow dari sistem informasi yang telah dibangun sehingga membutuhkan waktu yang lama untuk melakukan pengkodean.

10. Manfaat Sistem Informasi

a. Pengumpulan data menggunakan aplikasi ini sangat mudah dan mempercepat dalam mengumpulkan data di lapangan, hal ini sangat berbeda dengan pengumpulan data yang dilakukan dengan cara manual. Data tekstual dan spasial langsung di kumpulkan di aplikasi ini sehingga langsung tersinkronisasi antara kedua data ini dan tentunya membantu dalam proses pengolahan data nantinya. 
b. Aplikasi Si-Copilot dalam penggunaannya juga cukup mudah diaplikasikan. Pengguna cukup menginputkan data tekstual dan data spasial ke dalam aplikasi tersebut yang berisi data yang diperlukan dalam melengkapi informasi terhadap suatu bidang tanah instansi pemerintah.

c. Output dari basis data ini adalah seluruh titik bidang tanah yang sudah dilakukan inventarisasi terintegrasi dalam sebuah basis data sehingga mudah diakses sesuai kebutuhan. Basis data ini mempermudah Kantor Pertanahan Kabupaten Klaten di antaranya dalam hal: 1) pergeseran dari pengarsipan manual ke sistem digital, sehingga mengurangi kebutuhan ruangan arsip, 2) data yang dikumpulkan disimpan ke dalam basis data, sehingga proses pengelolaan lebih mudah, 3) monitoring progres kegiatan dan memudahkan untuk pembuatan pelaporan kegiatan INTIP.

d. Data inventarisasi bidang tanah instansi pemerintah menggunakan aplikasi SiCopilot yang sudah di export di software ArcGis, tidak perlu dilakukan join terhadap data tekstual dan spasial. Karena data yang dihasilkan di aplikasi SiCopilot sudah dalam format shpaefile berupa point-point bidang tanah yang sudah terintegrasi dengan data tekstualnya.

e. Dalam pelaksanaan penelitian ini, aplikasi Si-Copilot dirasakan sangat bermanfaat, dalam percepatan pengolahan data tekstual dan spasial. Proses pengolahan tidak perlu untuk melakukan entry dan join antara data tekstual dan spasial, sehingga dapat menghemat waktu dalam percepatan pengolahan data INTIP.

\section{Kesimpulan}

Permasalahan dan kendala dalam kegiatan INTIP di Kantor Pertanahan Kabupaten Klaten di antaranya; pelaksanaan pengumpulan data tekstual dan spasial dilakukan secara manual menggunakan hardcopy, pengumpulan data tekstual dan spasial dibedakan menjadi dua formulir yang berbeda, pengumpulan data tekstual dan spasial menggunakan hardcopy seringkali terdapat kesalahan penulisan dalam pengambilan data di lapangan, penyimpanan data hasil INTIP masih berupa hardcopy, terdapat adanya ketidak sinkronan antara data tekstual dan spasial karena pengerjaan tekstual dan spasial yang terpisah, pelaksanaan INTIP membutuhkan kerja sama dengan seksi lain, banyaknya target yang diberikan sehingga setiap tim mengalami kesulitan dalam melakukan manajemen data dan monitoring kegiatan INTIP yang tidak dapat dilakukan secara realtime. 
Sistem Informasi ini dirancang berupa software prototype yang dibangun mulai dari analisis kebutuhan pengguna dan sistem, pembuatan basis data, perancangan sistem informasi, uji coba, dan evaluasi sistem informasi. Sehingga dapat digunakan dalam membantu dalam pengumpulan data tekstual dan spasial untuk mempermudah pengolahan data sesuai dengan kebutuhan INTIP. Selain itu, sistem informasi yang dibangun juga menjawab atas permasalahan yang ada di kantor pertanahan.

Manfaat Sistem Informasi Collecting dan Plotting Pertanahan (Si-Copilot) dalam kegiatan INTIP adalah mampu mengumpul, mengolah, dan manajemen data tekstual dan data spasial secara bersamaan pada saat mengambil data di lokasi INTIP. Hal ini dapat memudahkan pengguna dalam mengintegrasikan data tekstual dan spasial sehingga dapat membantu percepatan penyelesaian pekerjaan INTIP.

\section{Rekomendasi}

1. Perlu penelitian dan pengembangan lebih lanjut terhadap aplikasi yang telah dibangun agar lebih baik, sehingga aplikasi tersebut menjadi lebih sempurna dan mengikuti kebutuhan pengguna seiring berjalannya waktu untuk mendukung program dari Kementerian ATR/BPN.

2. Hasil penelitian aplikasi yang dirancang oleh peneliti ini diharapkan menjadi rekomendasi Kementerian ATR/BPN dalam rangka untuk membantu pengumpulan dan manajemen kegiatan INTIP yang terdapat di seluruh Indonesia. Kantor pertanahan dapat menggunakan aplikasi yang dirancang oleh peneliti dalam pengumpulan data tekstual dan data spasial secara terintegrasi untuk keperluan INTIP. Selain itu, kantor pertanahan dapat bekerjasama dengan pemerintah daerah setempat untuk melakukan pemberdayaan dan pelatihan kepada masyarakat agar dapat melakukan pengumpulan data tekstual dan data spasial secara partisipatif untuk percepatan dalam melakukan inventarisasi tanah instansi pemerintah.

\section{Daftar Pustaka}

Abinowo. (2019). Rancang Bangun Aplikasi Pengintegrasian Data Fisik dan Data Yuridis Dalam Kegiatan Pendaftaran Tanah Sistematis Lengkap: Studi di Kantor Pertanahan Kabupaten Bantul. (Skripsi). Sekolah Tinggi Pertanahan Nasional. Yogyakarta

Forman, M. (2005). Using IT to Transform the Effectiveness and Efficiency of Goverment. Journal E-Government and Information Technology, Pg. 27.

Hardiansyah. (2020). Penataan Data Pertanahan Digital Terintegrasi: Studi di Kantor Pertanahan Kota Cirebon. (Skripsi). Sekolah Tinggi Pertanahan Nasional. Yogyakarta 
Hayati, M. (2019). Rancang Bangun Sistem Informasi Penguasaan Pemilikan Penggunaan dan Pemanfaatan Tanah (Studi di Kantor Pertanahan Kota Bukittinggi, Provinsi Sumatera Barat). (Skripsi) Sekolah Tinggi Pertanahan Nasional. Yogyakarta.

Indrajit. (2002). Electronic government (Startegi Pembangunan dan Pengembangan Sistem Pelayanan Publik Berbasis Teknologi Digital). Andi: Yogyakarta

Kementerian ATR/BPN. (2020, Juli 20) Inventarisasi Tanah Instansi Pemerintah (INTIP)[Video].YouTube,https://www.youtube.com/watch?v=xcrzWT_LphI\&t=s

Kementerian ATR/BPN. (2019). Petunjuk Teknis Nomor 5/JUKNIS-600.TP.03.01/XII/2019 tentang Inventarisai Tanah Instansi Pemerintah Jakarta: Dirjen Pengadaan Tanah.

Nidhra, S., \& Dondeti, J. (2012). Black box and white box testing techniques-a literature review. International Journal of Embedded Systems and Applications (IJESA), 2(2), 29-50.

Peraturan Menteri Agraria dan Tata Ruang/Kepala Badan Pertanahan Nasional Republik Indonesia Nomor 16 Tahun 2020 tentang Organisasi dan Tata Kerja Kementerian Agraria dan Tata Ruang/Badan Pertanahan Nasional

Puspitasari, F.E. (2015). Rancang Bangun Sistem Informasi Sertipikasi Tanah Kantor Pertanahan Kabupaten Kebumen. (Skripsi). Universitas Negeri Semarang. Semarang.

Rosa, A.S., \& Salahuddin, M. (2011). Modul Pembelajaran Rekayasa Perangkat Lunak (Terstruktur dan Berorientasi Objek). Bandung: Modula.

Satya, V. E. (2018). Strategi Indonesia menghadapi industri 4.0. Info Singkat, 10(9), 19-24.

Sugiarti, Y. (2016), Analisis dan Perancangan UML (Unified Modelling Language) VB.6. Yogyakarta: Graha Ilmu.

Salahudin, M., \& Rosa, A. S. (2013). Rekayasa Perangkat Lunak Terstruktur dan Berorientasi Objek. Bandung: Informatika.

Surdin, J. (2016). Analisis kelayakan implementasi e-government dalam pelayanan publik di bidang keagrariaan di kabupaten pinrang. KAREBA: Jurnal Ilmu Komunikasi, 178-191. 